\title{
Depicting Determinants and Effects of Intimacy and Verbal Aggressiveness Target through Social Network Analysis
}

\author{
Nikolaos Hasanagas, Alexandra Bekiari \\ Department of Physical Education and Sports, University of Thessaly, Thessaly, Greece \\ Email: n.hasanagas@gmail.com
}

Received 12 June 2015; accepted 13 July 2015; published 16 July 2015

Copyright (C) 2015 by authors and Scientific Research Publishing Inc. This work is licensed under the Creative Commons Attribution International License (CC BY). http://creativecommons.org/licenses/by/4.0/

cc) (i)

Open Access

\begin{abstract}
Aim of this research is to suggest determinants and effects of intimacy (including also its extreme forms such erotic relation or life-partnership), measured in term of its effect, attraction, as well as to analyze relations between attraction and verbal aggressiveness. Complete social network analysis has been conducted in a class of students of Physical Education Department, University of Thessaly $(\mathrm{N}=53)$. The data were collected with standardized questionnaires. Network analysis software (Visone) as well as cross-sectional analysis (SPSS) has been implemented. The results are: Attractiveness is gender-specific, as it is connected with male students. Younger students tend to be more attractive in physical appearance and dressing. The mother's pedagogic influence becomes evident on the attractiveness of someone for life-partnership. The academic conformity is not conducive to the development of pleasant discussions. Spending money for entertainment and impressing try to outweigh attractive physical appearance. Being aware of preference for durable erotic relation strengthens self-confidence. A companionship seems to be of socio-intellectual or of emotional-sexual nature. Attractiveness seems to lead to verbal aggression. It seems also to reduce the tendency to escape to imaginary sceneries. Physical dimension appears to be stronger than mental parameters for maintaining a durable erotic relation. The desire for life-partnership without children appears to be favored by mental elements. Verbal-aggressors search for targets without meticulously examining weaknesses and strengths on each person. Distinct types of attractiveness are also detected, corresponding to the following patterns: general sociability ("friend") which is also connected with mild (narcissistic) exploitation, erotic relation ("erotic") which is an autonomous value system based on superficial criteria related to appearance, focusing on communication ("distant communicable"), being an idol ("fully narcissistically exploitable") without any reality basis, and life-long occupation of a person ("life-long exploitable").
\end{abstract}




\section{Keywords}

\section{Intimacy, Verbal Aggressiveness, Attractiveness}

\section{Introduction}

How attractive an instructor is can be regarded as a communicational dimension. The attractiveness is a notion describing the capacity to gain appreciation and positive feelings from others (Berscheid \& Hatfield-Walster, 1969). In other words, a certain degree of intimacy is necessary to be attracted by someone. One cannot feel attracted by someone whose values, behavioral patterns and way of thinking are totally unfamiliar to him. Slight cases of intimacy are companionship, pleasant or personal discussion, communication and stronger cases of intimacy effect are the attractiveness for durable erotic relation or for life-partnership (cf. Giddens, 1992; Kelly, 1998; Popitz, 1992; Hasanagas, 2009).

According to this argumentation, attractiveness and subsequently the necessary degree of intimacy are expected to be factors relevant to the development and sustainability of social relations (cf. Unal-Colak \& Kobak, 2011).

McCroskey and McCain (1974) suggested a multidimensional framework of measuring the interpersonal attractiveness. Three dimensions of interpersonal attraction were in included in this model: desire to cooperate (task attractiveness), socialization (social attractiveness), and attractive physical appearance (physical attractiveness). Highly attractive individuals seem to be more persuasive and credible (McCroskey, Hamilton, \& Weiner, 1974). Attraction has been explored in relation to the quantity as well as to its quality (McCroskey et al., 1974).

Attractiveness has been examined in the setting of educational communications. It has been supported that perception of attractiveness is positively correlated with the immediacy and similarity in terms of attitudes and background (Edwards \& Edwards, 2001; McCroskey et al., 2006; Rocca \& McCroskey, 1999). Attractiveness and motivation to communicate or to learning are positively correlated (Myers \& Huebner, 2011; Unal-Colak \& Kobak, 2011).

Verbal aggressiveness is defined as an attack on an individual's self-concept instead of or in addition to attacking the person's position on a topic of communication, to inflict psychological pain (Infante \& Wigley, 1986). Research consistently shows that verbal aggression leads to negative relational outcomes (Infante, Myers, \& Buerkel, 1994; Martin \& Anderson, 1996; Infante \& Rancer, 1996; Bekiari, 2012, 2014). Martin et al. (1999) argued that there was a negative relationship between verbal aggression and social attraction. Instructor's use of slang and verbal aggression was related to negative student perceptions of the teacher (Martin et al., 1997). Verbal aggression was negatively related to perceptions of immediacy and interpersonal attraction (Rocca \& McCroskey, 1999). Myers (2003) identified six categories of instructor behaviours that constituted perceived instructor verbal aggressiveness (misbehaviors, non-immediacy, attacks on student competence, criticism of studentship behaviors, attacks on student personal attributes and discouragement of student participation). Bekiari and Hasanagas (2015) have thoroughly explored determinants of verbal aggressiveness through the holistic approach of complete network analysis, not focusing, however, on the parameter of attractiveness.

A significant negative relationship was noted between perceived instructor affinity seeking and perceived instructor verbal aggressiveness (Myers, and Members of COM 200 Creighton University, 2003). In addition, Myers (2001) indicated that perceived credibility (competence, character and caring) was negatively correlated with perceived verbal aggressiveness. Myers (2002) revealed that students' reports of instructors who were perceived as both high in argumentativeness and low in verbal aggressiveness were positively correlated with their own reports of state motivation, affective learning, cognitive learning and satisfaction.

It has been supported that attractiveness (social, professional and physical) and verbal aggressiveness present a negative relation to each other (Rocca \& McCroskey, 1999). Weiss and Houser (2007) suggested that students attracted by the professional conscientiousness, the sociability and the appearance of their instructor, were more willing to communicate and maintain a friendly relation with him as well as to be interested in the content of the lesson. They also proposed that a strong determinant of the social and physical attractiveness was the development of friendly relation. 
Aim of this research is to suggest determinants and effects of intimacy, measured in term of its effect, attraction, as well as to analyze relations between attraction and verbal aggressiveness. The expected innovation lies in the implementation of complete network analysis which is expected to depict more objectively the structures of attractiveness and verbal aggressiveness.

\section{Method}

Complete network analysis focuses in general on actor interactions, including also communication as well as power relations (Cook \& Emerson, 1978; Skvoretz \& Willer, 1993; Evans, 2001; Jordan \& Schubert, 1992). The class of $n$ students is visually depicted as a polygon (n-gon). This is actually a network of $n$ nodes and the diagonals are the links among them (e.g. relations of trust, attractiveness) (e.g. A trusts B, or A depends on the help of B, C and D). The polygon is useful as an illustration. However, in order to become algebraically processible, this network is converted in a matrix where the students are placed in the same order on both the vertical and horizontal axes. Its elements are the values of the relation from the vertical to horizontal axis (e.g. from A to $\mathrm{B}$ : no attractiveness $=0$, attractiveness $=1$ ). The length of a chain of successive trust relations (A trusts $\mathrm{B}$, $\mathrm{B}$ trusts $\mathrm{C}$ and $\mathrm{C}$ trusts $\mathrm{D}$ ) is also of importance, because it expresses the trust "status" of actor D in the network (formula of Katz, 1953, see also Foster et al., 2001; Bickson \& Malkhi, 2008). In this example, the actor D who has the highest trust status can influence actors C, B and A, by advising only C. Status of attractiveness can be similarly defined.

The following network analysis algorithms have been used, which are measured by Visone software in normalized form (\%). Their meaning (social interpretation) is here described without presenting any formulas which are complicated and accessible in the web.

1) in-degree (occasional hierarchy position)

It is defined as percentage of diagonal interactions received by a certain node. It can be interpreted as an occasional property given by the first-contacted nodes.

2) status (accumulative hierarchy position)

Status is here calculated as a power series (Katz, 1953). It expresses chains of relations as explained above. It can be interpreted as a situation more strongly established than simple indegree. However, its disadvantage in comparison with indegree is that it it does not present how many the links are through which a node may achieve an immediate impact.

3) pagerank (distributive hierarchy position)

It is based on the transferred value (e.g. being attracted, trusting) or depreciation (e.g. being insulted) from one node to others. Thus, a pagerank property is quite similar to this of Katz status. However, it yields more subtly differentiated values between the nodes, avoiding outliers. Furthermore, it avoids certain calculated deformations caused by Katz status.

4) authority (qualified competitiveness)

This points out a node with whom many other nodes maintain direct links. It may seem to have a meaning similar to this of in-degree but it has a main difference: It does not plainly express how many link-givers intend to maintain direct contact to someone (receiver) but how many other receivers these givers have. Namely, high authority characterizes a student who has attracted links of many other students who intensively (not occasionally) are looking for something specific.

The following examples of visualized networks are presented (Figure 1).

The higher the layer a node (student) is located in each "pyramid" (Figure 1), the more attractive it is or the more it becomes a target for verbal aggression in terms of Katz status, pagerank and authority respectively.

\subsection{Sample}

Network ("snowball”) sampling has been conducted. The whole network was a class of 53 students ( $4^{\text {th }}$ semester) from Physical Education Faculty of the University of Thessaly (Trikala) in Mai 2014. The sample consisted of 31 male and 22 female, aged from 20 to $46(\mathrm{M}=21, \mathrm{SD}=3.69)$. The participants came from various regions of Greece and belonged to different socio-economic status. The questionnaires were distributed to them and returned during the lesson. Thus, the response rate was $100 \%$. All questionnaires were valid. It was certified to them that the questionnaires will be handled with discretion and the names will be known only to the researcher. It was also explained that each one could be informed his network position after the analysis but only with a 


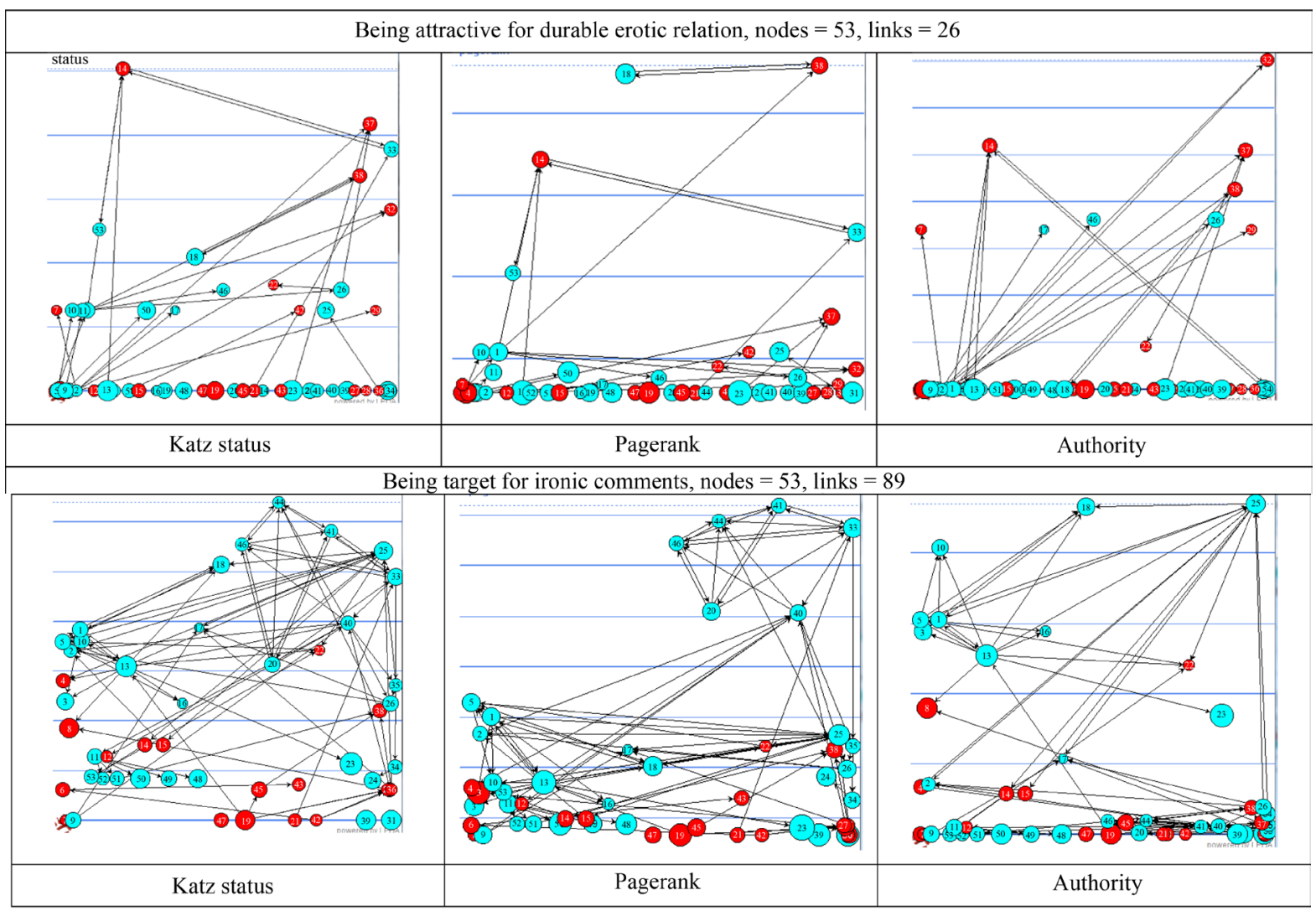

Figure 1. Examples of complete networks of 53 students in two kinds of relations (durable erotic relation and irony).

personal code number known only to him. In this way, sincerity was assured. The completion of questionnaires lasted for 20 - 30 minutes approximately and flowed freely. Furthermore, student participation in the process was voluntary, while those who did not wish to take part did not have to do so. Before completing the questionnaires, participants signed a consent form. The study was conducted in accordance to the best practice, ethics, and code of conduct.

All students were familiar with each other and have answered a standardized questionnaire about various relations developed among them. The questionnaires should be named, because otherwise a complete network analysis would be technically infeasible. However, it was emphasized to them that their names would be known only to the researcher. In this way, sincere information was expected to be received.

A network is by definition a non random sample. However, this is not considered to be a weakness, as purpose of this research was not the descriptive statistics (generalization of any descriptive quantitative property) but the analytical statistics (correlations).

\subsection{Questionnaire}

The questionnaire consisted of two parts: 1) non-network variables (e.g. gender, birth year etc), and 2) network variables. The network variables were the interactions among students, major part of which were the attractiveness which is the effect of intimacy (cf. Giddens, 1992). The following dimensions of interpersonal attraction have been measured: a) physical (beautifulness and dressing), b) social (companionship in and outside faculty, frequent communication per internet, sms or phone calls, pleasant and personal conversations) and c) task attraction (trust in consulting in issues of humanities or natural sciences and possible cooperation) (McCroskey et al., 2006; Vogt, 1997).

Although these are de facto based on internalized patterns of ideals and values (one is not attracted by a person who is not in accordance with his patterns and value system), and thereby on intimacy feeling, the questionnaire has been fostered with additional and more explicit forms of intimacy effects. These have been derived 
from explorative interviews with students and are the following: 1) short erotic relation by "love at first sight”, 2) durable erotic relation, 3) desire for life-partnership without children, and 4) with children.

Verbal aggressiveness dimensions have also been used from the Infante and Wigley (1986) (e.g. irony, offensiveness, criticism on intellectual, physical appearance, social background).

\subsection{Statistical Analysis}

The network data were processed by Visone 1.1 software. Afterwards, both non-network and network variables were entered in SPSS 21. After normality control with Kolmogorov-Smorinov and Shapiro-Wilk, bivariate correlation Spearman was applied. The interpretation was focused on statistically significant coefficients $\left(^{* *}: \mathrm{p} \leq\right.$ 0.05 and ${ }^{*}: \mathrm{p} \leq 0.01$ ). The bivariate analysis was preferred to multivariate analysis because it reveals many more correlations among variables. Multivariate analysis is more appropriate for examining fewer and more specific variables. Principal component analysis was also used for formulating typology. The interpretation of the results has been based on in-depth interviews.

\section{Results}

\subsection{Personal Determinants}

The gender appears to be of utmost importance for certain forms of intimacy. One feels stronger intimacy with male students for developing pleasant discussions from every point of view, occasional, accumulative, distributive as well as in qualified competitiveness $(-0.460,-0.427,-0.356,-0.318$, respectively). On the other hand, female students are more preferable for short erotic relations, as expected (0.393).

Younger students have a more attractive physical appearance $(0.287,0.284,0.367,0.345)$ and dressing $(0.300)$. The parents' education level, particularly mother's level, seems to influence the sociability and subsequently the attractiveness of someone for life partnership ( 0.326 to 0.294$)$. Students with high school grade $(-0.381$ to -0.333 ) are not attractive for pleasant discussion, which are normally identified with relaxing and joking.

Students with not attractive physical appearance $(-0.343)$ try to outweigh this weakness by spending more resources (money) either for personal entertainment and escape from disappointing situations or even for impressing others and gaining their respect. Students who are considered to have attractive dressing $(-0.376)$ or are attractive for short erotic relation $(-0.368)$, normally realize these attitudes of the others toward them and feel this situation as depreciative. On the contrary, those who are preferred for durable erotic relation (0.339 to 0.340) have developed enough self-confidence. Maintaining wide company group is an evidence of attractiveness for pleasant discussion (0.302) as well as for attractiveness for durable erotic relation (0.329 to 0.316) (Table 1$)$.

\subsection{Intimacy and Verbal Aggressiveness}

In Table 2, it is noticeable that several dimensions of attractiveness such as physical appearance $(0.291$ and 0.368 ), dressing ( 0.357 to 0.458 ), pleasant discussion ( 0.563 to 0.659 ) and pleasant discussion ( 0.580 to 0.720 ) are positively correlated with dimensions of verbal aggression (irony and aggression by phone or face-to-face).

\subsection{The Role of Imagination}

Table 3 offers clear evidences that students who are attractive in reality do not need to escape to any imaginary sceneries. They especially do not need to imagine any pleasant companionship ( -0.393 to -0.350$)$. Additionally, students with attractive physical appearance do not need any supplement of imaginary verbal aggressiveness $(-0.289)$ as they normally have a real imposing appearance. Those who are attractive for short erotic relation do not need any escape to imaginary cooperation relation $(-0.287)$ which might have given an additional point to their life.

The results of Table 4 complement and support the results of Table 3. Not only imaginary relations but also imaginary places tend to be a substitute for lack of attractiveness. The lack of attractiveness for short erotic relation mostly seems to constitute the strongest need for escaping to imaginary places $(-0.329$ to -0.329$)$. The weak physical appearance $(-0.283$ and -0.326$)$, the unattractive dressing $(-0.278)$ and the lack of attractiveness for life partnership without $(-0.323)$ or with children $(-0.280)$ also slightly tend to lead to imaginary escape solutions. 
Table 1. The role of personal features in attractiveness.

\begin{tabular}{|c|c|c|c|c|c|c|c|c|}
\hline & $\begin{array}{c}\text { Gender: } \\
\text { Male }=0 \\
\text { Female }=1\end{array}$ & $\begin{array}{l}\text { Birth } \\
\text { year }\end{array}$ & $\begin{array}{l}\text { Mother } \\
\text { education }\end{array}$ & $\begin{array}{l}\text { School } \\
\text { grade }\end{array}$ & $\begin{array}{l}\text { Month } \\
\text { expenses a }\end{array}$ & $\begin{array}{l}\text { Perceived } \\
\text { appreciation al }\end{array}$ & $\begin{array}{l}\text { Ignore } \\
\text { appreciation }\end{array}$ & $\begin{array}{l}\text { Closest company } \\
\text { group (number } \\
\text { of persons) }\end{array}$ \\
\hline \multirow[t]{2}{*}{ Attractive physical appearance (indegree) } & 0.015 & $0.287\left(\left(^{*}\right)\right.$ & 0.114 & -0.223 & 0.035 & -0.226 & 0.100 & 0.078 \\
\hline & 0.916 & 0.041 & 0.435 & 0.124 & 0.815 & 0.221 & 0.486 & 0.597 \\
\hline \multirow[t]{2}{*}{ Attractive physical appearance (Katz status) } & -0.011 & $0.284\left({ }^{*}\right)$ & 0.089 & -0.223 & 0.004 & -0.217 & 0.117 & 0.076 \\
\hline & 0.940 & 0.043 & 0.545 & 0.124 & 0.980 & 0.240 & 0.412 & 0.602 \\
\hline \multirow[t]{2}{*}{ Attractive physical appearance (pagerank) } & 0.165 & $0.367\left(^{* *}\right)$ & 0.093 & -0.228 & $-0.343\left({ }^{*}\right)$ & -0.181 & -0.023 & 0.208 \\
\hline & 0.247 & 0.008 & 0.527 & 0.115 & 0.017 & 0.329 & 0.872 & 0.151 \\
\hline \multirow[t]{2}{*}{ Attractive physical appearance (authority) } & 0.041 & $0.345\left({ }^{*}\right)$ & -0.014 & -0.169 & 0.035 & -0.135 & 0.203 & -0.054 \\
\hline & 0.777 & 0.013 & 0.923 & 0.246 & 0.814 & 0.469 & 0.152 & 0.711 \\
\hline \multirow[t]{2}{*}{ Attractive dressing (indegree) } & 0.074 & 0.300() & 0.136 & -0.076 & 0.140 & -0.325 & 0.170 & 0.112 \\
\hline & 0.605 & 0.032 & 0.352 & 0.602 & 0.344 & 0.075 & 0.232 & 0.443 \\
\hline \multirow[t]{2}{*}{ Attractive dressing (pagerank) } & 0.272 & 0.221 & 0.231 & -0.025 & 0.177 & $-0.376\left({ }^{*}\right)$ & 0.154 & 0.073 \\
\hline & 0.053 & 0.118 & 0.110 & 0.867 & 0.230 & 0.037 & 0.280 & 0.618 \\
\hline \multirow[t]{2}{*}{ Attractive for pleasant discussion (indegree) } & $-0.460\left(^{* *}\right)$ & 0.048 & -0.102 & $-0.381\left(^{* *}\right)$ & 0.047 & 0.014 & 0.110 & $0.302\left(^{*}\right)$ \\
\hline & 0.001 & 0.739 & 0.485 & 0.007 & 0.752 & 0.940 & 0.441 & 0.035 \\
\hline \multirow[t]{2}{*}{ Attractive for pleasant discussion (Katz status) } & $-0.427\left({ }^{* *}\right)$ & 0.077 & -0.133 & $-0.368\left(^{* *}\right)$ & 0.032 & 0.074 & 0.149 & 0.246 \\
\hline & 0.002 & 0.590 & 0.362 & 0.009 & 0.827 & 0.692 & 0.297 & 0.089 \\
\hline \multirow[t]{2}{*}{ Attractive for pleasant discussion (pagerank) } & $-0.356\left(^{*}\right)$ & 0.090 & -0.163 & $-0.300\left({ }^{*}\right)$ & 0.044 & -0.010 & 0.041 & 0.174 \\
\hline & 0.010 & 0.529 & 0.263 & 0.036 & 0.764 & 0.957 & 0.775 & 0.232 \\
\hline \multirow[t]{2}{*}{ Attractive for pleasant discussion (authority) } & $-0.318\left({ }^{*}\right)$ & 0.228 & -0.082 & $-0.333\left({ }^{*}\right)$ & 0.029 & 0.121 & 0.236 & 0.199 \\
\hline & 0.023 & 0.107 & 0.575 & 0.019 & 0.846 & 0.518 & 0.095 & 0.171 \\
\hline \multirow[t]{2}{*}{ Attractive for durable erotic relation (indegree) } & 0.011 & -0.102 & 0.053 & -0.018 & 0.021 & 0.067 & $0.339\left({ }^{*}\right)$ & $0.329\left({ }^{*}\right)$ \\
\hline & 0.938 & 0.474 & 0.720 & 0.901 & 0.886 & 0.721 & 0.015 & 0.021 \\
\hline \multirow[t]{2}{*}{ Attractive for durable erotic relation (Katz status) } & 0.000 & -0.102 & 0.020 & -0.025 & -0.016 & 0.060 & $0.364\left(^{* *}\right)$ & $0.314\left({ }^{*}\right)$ \\
\hline & 10.000 & 0.475 & 0.891 & 0.864 & 0.916 & 0.749 & 0.009 & 0.028 \\
\hline \multirow[t]{2}{*}{ Attractive for durable erotic relation (pagerank) } & -0.024 & -0.099 & 0.072 & -0.052 & -0.026 & 0.060 & $0.340\left({ }^{*}\right)$ & 0.272 \\
\hline & 0.868 & 0.491 & 0.624 & 0.723 & 0.861 & 0.750 & 0.015 & 0.058 \\
\hline \multirow[t]{2}{*}{ Attractive for durable erotic relation (authority) } & 0.242 & -0.016 & -0.076 & 0.188 & 0.094 & -0.086 & 0.248 & $0.316\left({ }^{*}\right)$ \\
\hline & 0.087 & 0.911 & 0.604 & 0.196 & 0.523 & 0.647 & 0.079 & 0.027 \\
\hline \multirow[t]{2}{*}{ Attractive for short erotic relation (authority) } & $0.393\left(^{* *}\right)$ & 0.126 & 0.196 & 0.281 & 0.087 & $-0.368\left(\left(^{*}\right)\right.$ & 0.140 & 0.135 \\
\hline & 0.004 & 0.378 & 0.177 & 0.051 & 0.556 & 0.042 & 0.327 & 0.356 \\
\hline \multirow[t]{2}{*}{$\begin{array}{l}\text { Attractive for lifepatnership without } \\
\text { children (indegree) }\end{array}$} & 0.234 & -0.095 & $0.326\left({ }^{*}\right)$ & -0.039 & -0.012 & -0.334 & 0.148 & 0.006 \\
\hline & 0.099 & 0.509 & 0.022 & 0.789 & 0.933 & 0.067 & 0.299 & 0.968 \\
\hline \multirow[t]{2}{*}{$\begin{array}{l}\text { Attractive for lifepatnership without } \\
\text { children (Katz status) }\end{array}$} & 0.216 & -0.119 & $0.329\left(^{*}\right)$ & -0.049 & -0.003 & -0.327 & 0.150 & 0.008 \\
\hline & 0.127 & 0.406 & 0.021 & 0.737 & 0.984 & 0.073 & 0.294 & 0.956 \\
\hline \multirow[t]{2}{*}{$\begin{array}{l}\text { Attractive for lifepatnership without } \\
\text { children (pagerank) }\end{array}$} & 0.209 & -0.090 & $0.295\left({ }^{*}\right)$ & -0.058 & -0.038 & -0.320 & 0.182 & -0.002 \\
\hline & 0.141 & 0.531 & 0.040 & 0.693 & 0.798 & 0.079 & 0.201 & 0.989 \\
\hline \multirow[t]{2}{*}{ Attractive for lifepatnership with children (indegree) } & 0.259 & -0.164 & $0.396\left(^{* *}\right)$ & 0.149 & -0.051 & -0.310 & 0.181 & -0.197 \\
\hline & 0.066 & 0.250 & 0.005 & 0.307 & 0.729 & 0.090 & 0.204 & 0.174 \\
\hline \multirow[t]{2}{*}{$\begin{array}{l}\text { Attractive for lifepatnership } \\
\text { with children (Katz status) }\end{array}$} & 0.251 & -0.183 & $0.383\left({ }^{* *}\right)$ & 0.136 & -0.045 & -0.303 & 0.190 & -0.162 \\
\hline & 0.076 & 0.199 & 0.007 & 0.353 & 0.759 & 0.097 & 0.181 & 0.265 \\
\hline \multirow[t]{2}{*}{ Attractive for lifepatnership with children (pagerank) } & 0.232 & -0.138 & $0.367\left(^{* *}\right)$ & 0.109 & -0.070 & -0.320 & 0.219 & -0.210 \\
\hline & 0.101 & 0.335 & 0.009 & 0.455 & 0.638 & 0.079 & 0.123 & 0.148 \\
\hline \multirow[t]{2}{*}{ Attractive for lifepatnership with children (authority) } & 0.138 & -0.250 & $0.294\left({ }^{*}\right)$ & 0.117 & -0.087 & -0.086 & 0.146 & 0.036 \\
\hline & 0.334 & 0.077 & 0.040 & 0.424 & 0.557 & 0.647 & 0.307 & 0.807 \\
\hline
\end{tabular}

${ }^{* *}$ Correlation is significant at the 0.01 level (2-tailed). ${ }^{*}$ Correlation is significant at the 0.05 level (2-tailed). 
Table 2. Intimacy and verbal aggressiveness targeting.

\begin{tabular}{|c|c|c|c|c|}
\hline & $\begin{array}{c}\text { Total attractive physical } \\
\text { appearance }\end{array}$ & $\begin{array}{l}\text { Total attractive } \\
\text { dressing }\end{array}$ & $\begin{array}{l}\text { Total attractive for } \\
\text { pleasant discussion }\end{array}$ & $\begin{array}{c}\text { Total attractive } \\
\text { for personal discussion }\end{array}$ \\
\hline \multirow[t]{2}{*}{ Total irony } & $0.291\left(^{*}\right)$ & $0.357\left(^{* *}\right)$ & $0.563\left(^{* *}\right)$ & $0.580\left({ }^{* *}\right)$ \\
\hline & 0.035 & 0.009 & 0.000 & 0.000 \\
\hline \multirow[t]{2}{*}{$\begin{array}{l}\text { Total aggression by } \\
\text { phone }\end{array}$} & 0.179 & $0.292\left({ }^{*}\right)$ & $0.533\left({ }^{* *}\right)$ & $0.569\left(^{* *}\right)$ \\
\hline & 0.199 & 0.034 & 0.000 & 0.000 \\
\hline \multirow[t]{2}{*}{$\begin{array}{l}\text { Total aggression } \\
\text { face-to-face }\end{array}$} & $0.368\left(^{* *}\right)$ & $0.458\left(^{* *}\right)$ & $0.659\left(^{* *}\right)$ & $0.720\left(^{* *}\right)$ \\
\hline & 0.007 & 0.001 & 0.000 & 0.000 \\
\hline
\end{tabular}

${ }^{* *}$ Correlation is significant at the 0.01 level (2-tailed). ${ }^{*}$ Correlation is significant at the 0.05 level (2-tailed). "Total” means sum of all network algorithms (indegree, Katz status, pagerank, authority).

Table 3. Intimacy and imaginary relations.

\begin{tabular}{|c|c|c|c|c|}
\hline & $\begin{array}{c}\text { Total attractive } \\
\text { physical appearance }\end{array}$ & $\begin{array}{l}\text { Total attractive } \\
\text { dressing }\end{array}$ & $\begin{array}{l}\text { Total attractive for } \\
\text { short erotic relation }\end{array}$ & $\begin{array}{l}\text { Total attractive life partnership } \\
\text { without children }\end{array}$ \\
\hline \multirow[t]{2}{*}{ Sum of pleasure } & $-0.393\left(^{* *}\right)$ & $-0.402\left(^{* *}\right)$ & $-0.428\left(^{* *}\right)$ & $-0.350\left({ }^{*}\right)$ \\
\hline & 0.004 & 0.003 & 0.002 & 0.012 \\
\hline \multirow[t]{2}{*}{ Sum of negative comments } & $-0.289\left(^{*}\right)$ & -0.237 & -0.066 & -0.171 \\
\hline & 0.044 & 0.101 & 0.657 & 0.241 \\
\hline \multirow[t]{2}{*}{ Sum of cooperation } & -0.261 & -0.242 & $-0.287\left({ }^{*}\right)$ & -0.169 \\
\hline & 0.064 & 0.088 & 0.043 & 0.236 \\
\hline
\end{tabular}

${ }^{* *}$ Correlation is significant at the 0.01 level (2-tailed). ${ }^{*}$ Correlation is significant at the 0.05 level (2-tailed). "Total” means sum of all network algorithms (indegree, Katz status, pagerank, authority). "Sum” means the whole occurrence of every imaginary relation in all hypothetical sceneries.

Table 4. Intimacy and imaginary placing.

\begin{tabular}{|c|c|c|c|c|c|}
\hline & $\begin{array}{c}\text { Total attractive } \\
\text { physical } \\
\text { appearance }\end{array}$ & $\begin{array}{c}\text { Total attractive } \\
\text { dressing }\end{array}$ & $\begin{array}{l}\text { Total attractive for } \\
\text { short erotic relation }\end{array}$ & $\begin{array}{c}\text { Total attractive life } \\
\text { partnership } \\
\text { without children }\end{array}$ & $\begin{array}{c}\text { Total attractive } \\
\text { life partnership with } \\
\text { children }\end{array}$ \\
\hline \multirow[t]{2}{*}{ Sum of cafeteria } & -0.200 & -0.166 & $-0.329\left(^{*}\right)$ & -0.178 & -0.076 \\
\hline & 0.159 & 0.244 & 0.019 & 0.212 & 0.598 \\
\hline \multirow[t]{2}{*}{ Sum of bar } & $-0.283\left(\left(^{*}\right)\right.$ & -0.230 & $-0.428\left(^{* *}\right)$ & -0.237 & -0.122 \\
\hline & 0.045 & 0.104 & 0.002 & 0.094 & 0.392 \\
\hline \multirow[t]{2}{*}{ Sum of restaurant } & -0.258 & -0.175 & $-0.337\left(\left(^{*}\right)\right.$ & -0.250 & -0.131 \\
\hline & 0.068 & 0.218 & 0.017 & 0.077 & 0.360 \\
\hline \multirow[t]{2}{*}{ Sum of tavern } & $-0.326\left(^{*}\right)$ & $-0.278\left(^{*}\right)$ & -0.252 & $-0.323\left(^{*}\right)$ & $-0.280\left(^{*}\right)$ \\
\hline & 0.019 & 0.048 & 0.077 & 0.021 & 0.046 \\
\hline \multirow[t]{2}{*}{ Sum of other place } & -0.262 & -0.260 & $-0.329\left(^{*}\right)$ & -0.132 & -0.142 \\
\hline & 0.069 & 0.071 & 0.022 & 0.365 & 0.331 \\
\hline
\end{tabular}

${ }^{* *}$ Correlation is significant at the 0.01 level (2-tailed). ${ }^{*}$ Correlation is significant at the 0.05 level (2-tailed). "Total” means sum of all network algorithms (indegree, Katz status, pagerank, authority). "Sum” means the whole occurrence of every imaginary place in all hypothetical relations.

Looking more insightfully to the personal imaginary patterns of the students (Table 5) it is noticeable that pleasure of companionship seems to be compatible with any type of place, built or natural (0.378 to 0.435$)$. The erotic relation seems also to be compatible with any type of place in the imagination of the students $(0.497$ to 0.518). Personal discussion (0.293 to 0.610$)$, cooperation (0.595 to 0.333 ) and negative criticism (0.450 to 0.284$)$ tend to be compatible with various places. 
Table 5. Imaginary placing and imaginary relations.

\begin{tabular}{|c|c|c|c|c|c|c|}
\hline & $\begin{array}{l}\text { Sum of } \\
\text { pleasure }\end{array}$ & $\begin{array}{l}\text { Sum of } \\
\text { erotic }\end{array}$ & $\begin{array}{l}\text { Sum of personal } \\
\text { discussion }\end{array}$ & $\begin{array}{l}\text { Sum of } \\
\text { cooperation }\end{array}$ & $\begin{array}{l}\text { Sum of negative } \\
\text { comments }\end{array}$ & $\begin{array}{l}\text { Sum of } \\
\text { marriage }\end{array}$ \\
\hline \multirow[t]{2}{*}{ Sum of home } & $0.378\left(^{* *}\right)$ & $0.497\left(^{* *}\right)$ & 0.116 & $0.595\left(^{* *}\right)$ & 0.229 & $0.294\left({ }^{*}\right)$ \\
\hline & 0.006 & 0.000 & 0.416 & 0.000 & 0.113 & 0.041 \\
\hline \multirow[t]{2}{*}{ Sum of cafeteria } & $0.494\left({ }^{* *}\right)$ & $0.605\left({ }^{* *}\right)$ & 0.199 & $0.437\left(^{* *}\right)$ & $0.450\left(^{* *}\right)$ & 0.272 \\
\hline & 0.000 & 0.000 & 0.162 & 0.001 & 0.001 & 0.058 \\
\hline \multirow[t]{2}{*}{ Sum of bar } & $0.621\left({ }^{* *}\right)$ & $0.516\left(^{* *}\right)$ & 0.191 & $0.411\left({ }^{* *}\right)$ & $0.396\left(^{* *}\right)$ & 0.154 \\
\hline & 0.000 & 0.000 & 0.180 & 0.003 & 0.005 & 0.291 \\
\hline \multirow[t]{2}{*}{ Sum of restaurant } & $0.629\left(^{* *}\right)$ & $0.405\left(^{* *}\right)$ & $0.293\left(^{*}\right)$ & $0.436\left(^{* *}\right)$ & 0.221 & $0.286\left(^{*}\right)$ \\
\hline & 0.000 & 0.003 & 0.037 & 0.001 & 0.126 & 0.046 \\
\hline \multirow[t]{2}{*}{ Sum of tavern } & $0.685\left(^{* *}\right)$ & $0.393\left(^{* *}\right)$ & $0.353\left(^{*}\right)$ & $0.474\left(^{* *}\right)$ & $0.386\left(^{* *}\right)$ & 0.238 \\
\hline & 0.000 & 0.004 & 0.011 & 0.000 & 0.006 & 0.100 \\
\hline \multirow[t]{2}{*}{ Sum of park } & $0.566\left(^{* *}\right)$ & $0.506\left(^{* *}\right)$ & $0.517\left(^{* *}\right)$ & $0.388\left({ }^{* *}\right)$ & $0.484\left(^{* *}\right)$ & -0.032 \\
\hline & 0.000 & 0.000 & 0.000 & 0.005 & 0.000 & 0.829 \\
\hline \multirow[t]{2}{*}{ Sum of beach } & $0.394\left(^{* *}\right)$ & $0.442\left({ }^{* *}\right)$ & $0.549\left(^{* *}\right)$ & 0.107 & $0.317\left(^{*}\right)$ & 0.157 \\
\hline & 0.005 & 0.001 & 0.000 & 0.459 & 0.028 & 0.283 \\
\hline \multirow[t]{2}{*}{ Sum of lake } & $0.516\left(^{* *}\right)$ & $0.531\left(^{* *}\right)$ & $0.506\left(^{* *}\right)$ & $0.304\left({ }^{*}\right)$ & 0.153 & 0.113 \\
\hline & 0.000 & 0.000 & 0.000 & 0.030 & 0.293 & 0.438 \\
\hline \multirow[t]{2}{*}{ Sum of range } & $0.433\left(^{* *}\right)$ & $0.440\left(^{* *}\right)$ & $0.570\left(^{* *}\right)$ & $0.333\left(^{*}\right)$ & 0.121 & 0.125 \\
\hline & 0.002 & 0.001 & 0.000 & 0.018 & 0.412 & 0.392 \\
\hline \multirow[t]{2}{*}{ Sum of forest } & $0.435\left(^{* *}\right)$ & $0.518\left(^{* *}\right)$ & $0.610\left(^{* *}\right)$ & 0.169 & $0.284\left({ }^{*}\right)$ & 0.085 \\
\hline & 0.001 & 0.000 & 0.000 & 0.235 & 0.048 & 0.563 \\
\hline
\end{tabular}

${ }^{* *}$ Correlation is significant at the 0.01 level (2-tailed). ${ }^{*}$ Correlation is significant at the 0.05 level (2-tailed). "Sum” means the whole occurrence of every imaginary relation in all hypothetical sceneries and the whole occurrence of every imaginary place in all hypothetical relations, respectively.

Finally, it is remarkable that marriage seems to be mostly compatible with only a few places. These are home (0.294) and restaurant (0.286).

\subsection{Tendency of Extension}

In Table 6 the types of attractiveness appear to be compatible with each other to large extent. The dressing attractiveness is quite strongly compatible with physical appearance $(0.875)$. Thus, there seems to be an extension of positive feeling from dressing to physical appearance or inversely.

The attractive physical appearance (0.693) as well as the attractive dressing (0.696) seem to be conducive to developing attractiveness for pleasant discussion. The same stands for the case of personal discussion too $(0.585$, 0.633) while "personal" and "pleasant" discussion seems to be strongly in accordance with each other (0.807).

The attractiveness of durable erotic relation seems to be also in part based on physical appearance (0.304) and dressing (0.353) and not i.e. significantly on pleasant or attractive personal discussion. The same stands also for the short erotic relation $(0.356$ and 0.414$)$. It is also noticeable that a person tends to be simultaneously attractive for short and durable erotic relation (0.647).

The attractiveness for life partnership without children appears to be based also on mental dimension, particularly on the attractiveness for personal discussion (0.313). Additionally, it presents characteristics similar to these of erotic relation, meaning importance of attractive physical appearance (0.464) and dressing $(0.456)$. It is also correlated with durable (0.566) and short (0.689) erotic relation, as these may be previous stage for daring a life partnership. Similar interpretation may also be applied in the case of life partnership with children $(0.487$, $0.497,0.659)$.

In general, a person attractive in a sector, tends to be also attractive in other sectors. There is, thus, a tendency 
Table 6. Extension of intimacy.

\begin{tabular}{|c|c|c|c|c|c|c|c|}
\hline & $\begin{array}{c}\text { Total } \\
\text { attractive } \\
\text { dressing }\end{array}$ & $\begin{array}{l}\text { Total } \\
\text { attractive } \\
\text { for } \\
\text { pleasant } \\
\text { discussion }\end{array}$ & $\begin{array}{l}\text { Total } \\
\text { attractive } \\
\text { for } \\
\text { personal } \\
\text { discussion }\end{array}$ & $\begin{array}{l}\text { Total } \\
\text { attractive } \\
\text { for } \\
\text { durable } \\
\text { erotic } \\
\text { relation }\end{array}$ & $\begin{array}{l}\text { Total } \\
\text { attractive } \\
\text { for short } \\
\text { erotic } \\
\text { relation }\end{array}$ & $\begin{array}{l}\text { Total } \\
\text { attractive } \\
\text { for life } \\
\text { partnership } \\
\text { without } \\
\text { children }\end{array}$ & $\begin{array}{l}\text { Total } \\
\text { attractive } \\
\text { for life } \\
\text { partnership } \\
\text { with } \\
\text { children }\end{array}$ \\
\hline \multirow[t]{2}{*}{$\begin{array}{c}\text { Total attractive physical } \\
\text { appearance }\end{array}$} & $0.875\left({ }^{* *}\right)$ & $0.693\left({ }^{* *}\right)$ & $0.585\left({ }^{* *}\right)$ & $0.304\left({ }^{*}\right)$ & $0.356\left(^{* *}\right)$ & $0.464\left({ }^{* *}\right)$ & 0.203 \\
\hline & 0.000 & 0.000 & 0.000 & 0.027 & 0.009 & 0.000 & 0.146 \\
\hline \multirow[t]{2}{*}{ Total attractive dressing } & & $0.696\left(^{* *}\right)$ & $0.633\left(^{* *}\right)$ & $0.353\left(^{* *}\right)$ & $0.414\left(^{* *}\right)$ & $0.456\left({ }^{* *}\right)$ & 0.179 \\
\hline & & 0.000 & 0.000 & 0.009 & 0.002 & 0.001 & 0.199 \\
\hline \multirow[t]{2}{*}{$\begin{array}{l}\text { Total attractive for pleasant } \\
\text { discussion }\end{array}$} & & & $0.807\left(^{* *}\right)$ & 0.181 & 0.046 & 0.218 & -0.036 \\
\hline & & & 0.000 & 0.196 & 0.747 & 0.117 & 0.796 \\
\hline \multirow[t]{2}{*}{$\begin{array}{l}\text { Total attractive for personal } \\
\text { discussion }\end{array}$} & & & & 0.172 & 0.157 & $0.313\left(\left(^{*}\right)\right.$ & 0.131 \\
\hline & & & & 0.219 & 0.266 & 0.022 & 0.350 \\
\hline \multirow[t]{2}{*}{$\begin{array}{l}\text { Total attractive for durable } \\
\text { erotic relation }\end{array}$} & & & & & $0.647\left(^{* *}\right)$ & $0.566\left(^{* *}\right)$ & $0.487\left(^{* *}\right)$ \\
\hline & & & & & 0.000 & 0.000 & 0.000 \\
\hline \multirow[t]{2}{*}{$\begin{array}{l}\text { Total attractive for short erotic } \\
\text { relation }\end{array}$} & & & & & & $0.689(* *)$ & $0.497\left(^{* *}\right)$ \\
\hline & & & & & & 0.000 & 0.000 \\
\hline \multirow[t]{2}{*}{$\begin{array}{l}\text { Total attractive for life } \\
\text { partnership without children }\end{array}$} & & & & & & & $0.659\left(^{* *}\right)$ \\
\hline & & & & & & & 0.000 \\
\hline
\end{tabular}

${ }^{* *}$ Correlation is significant at the 0.01 level (2-tailed). " Correlation is significant at the 0.05 level (2-tailed). "Total” means sum of all network algorithms (indegree, Katz status, pagerank, authority).

for extending initimacy.

In Table 7, a tendency of extending verbal aggressiveness is also obvious (numerous significant coefficients). One who tends to be criticized in his intellectual abilities, e.g. tends also to be a target of criticism on his behavior (0.803) etc.

\subsection{Suggesting a Typology}

Not all types of intimacy tend to be integrated together in every person and in any circumstances. They seem to appear in certain combinations (Table 8). Thus, the following types of intimacy can be suggested:

1) The "friend"

This is a person characterized by numerous of attractiveness dimensions. The others tend to feel enough intimacy toward him to desire his companionship in and outside of the faculty $(0.773,0.803)$, to communicate with him in any possible written form (internet, 0.763 , sms, 0.557 , phone calls, 0.795 and 0.628 ), to be attracted by his physical appearance $(0.636)$ and dressing $(0.711)$, to desire a pleasant $(0.872)$ or personal $(0.898)$ conversation with him as well as to tend to improve him according to their internalized criteria (0.492).

Thereby, this type means considerable investment of time and hopes for change to a "better" direction. Namely, this multidimensional attractiveness does not seem to constitute an influential person but rather a person who is regarded partially by the others as a subject of narcissistic exploitation (even in a mild way) and is expected by them to be influenceable. In simplified words, they like enough characteristics of him in order to desire his companion, communication etc but they want to change ("improve") him further according of course to their desirable patterns.

2) The "erotic"

This type seems to have gained enough intimacy from the others concerning his physical appearance $(0.435)$ 
Table 7. Extension of verbal aggressiveness targeting.

\begin{tabular}{|c|c|c|c|c|c|c|c|c|}
\hline & $\begin{array}{c}\text { Total } \\
\text { aggression } \\
\text { on behavior }\end{array}$ & $\begin{array}{c}\text { Total } \\
\text { aggression } \\
\text { on } \\
\text { appearance }\end{array}$ & $\begin{array}{c}\text { Total } \\
\text { aggression } \\
\text { on } \\
\text { background/ } \\
\text { milieu }\end{array}$ & $\begin{array}{l}\text { Total } \\
\text { irony }\end{array}$ & $\begin{array}{l}\text { Total } \\
\text { mockery }\end{array}$ & $\begin{array}{c}\text { Total verbal } \\
\text { aggression } \\
\text { via } \\
\text { email/sms }\end{array}$ & $\begin{array}{c}\text { Total } \\
\text { verbal } \\
\text { aggression } \\
\text { by phone }\end{array}$ & $\begin{array}{c}\text { Total verbal } \\
\text { aggression } \\
\text { face-to-face }\end{array}$ \\
\hline \multirow[t]{2}{*}{$\begin{array}{l}\text { Total aggression on } \\
\text { intellectual abilities }\end{array}$} & $0.803\left({ }^{* *}\right)$ & $0.747\left(^{* *}\right)$ & $0.560\left(^{* *}\right)$ & $0.508\left(^{* *}\right)$ & $0.393\left(^{* *}\right)$ & $0.417\left(^{* *}\right)$ & $0.341\left({ }^{*}\right)$ & 0.156 \\
\hline & 0.000 & 0.000 & 0.000 & 0.000 & 0.004 & 0.002 & 0.013 & 0.263 \\
\hline \multirow[t]{2}{*}{ Total aggression on behavior } & & $0.812\left(^{* *}\right)$ & $0.626\left(^{* *}\right)$ & $0.606\left({ }^{* *}\right)$ & $0.455\left(^{* *}\right)$ & $0.531\left({ }^{* *}\right)$ & $0.482\left(^{* *}\right)$ & $0.281\left(^{*}\right)$ \\
\hline & & 0.000 & 0.000 & 0.000 & 0.001 & 0.000 & 0.000 & 0.041 \\
\hline \multirow[t]{2}{*}{ Total aggression on appearance } & & & $0.637\left(^{* *}\right)$ & $0.533\left(^{* *}\right)$ & 0.253 & $0.407\left(^{* *}\right)$ & $0.386\left(^{* *}\right)$ & 0.265 \\
\hline & & & 0.000 & 0.000 & 0.068 & 0.003 & 0.004 & 0.055 \\
\hline \multirow[t]{2}{*}{$\begin{array}{l}\text { Total aggression on } \\
\text { background/milieu }\end{array}$} & & & & $0.528\left({ }^{* *}\right)$ & $0.303\left(\left(^{*}\right)\right.$ & $0.321\left({ }^{*}\right)$ & $0.391\left(^{* *}\right)$ & $0.320(*)$ \\
\hline & & & & 0.000 & 0.027 & 0.019 & 0.004 & 0.020 \\
\hline \multirow[t]{2}{*}{ Total irony } & & & & & $0.518\left(^{* *}\right)$ & $0.642\left(^{* *}\right)$ & $0.738\left(^{* *}\right)$ & $0.655\left(^{* *}\right)$ \\
\hline & & & & & 0.000 & 0.000 & 0.000 & 0.000 \\
\hline \multirow[t]{2}{*}{ Total mockery } & & & & & & $0.539\left(^{* *}\right)$ & $0.573\left(^{* *}\right)$ & $0.499\left(^{* *}\right)$ \\
\hline & & & & & & 0.000 & 0.000 & 0.000 \\
\hline \multirow[t]{2}{*}{$\begin{array}{l}\text { Total verbal aggression } \\
\text { via email/sms }\end{array}$} & & & & & & & $0.661\left(^{* *}\right)$ & $0.525\left({ }^{* *}\right)$ \\
\hline & & & & & & & 0.000 & 0.000 \\
\hline \multirow[t]{2}{*}{ Total verbal aggression by phone } & & & & & & & & $0.795\left(^{* *}\right)$ \\
\hline & & & & & & & & 0.000 \\
\hline
\end{tabular}

${ }^{* *}$ Correlation is significant at the 0.01 level (2-tailed). ${ }^{*}$ Correlation is significant at the 0.05 level (2-tailed). "Total” means sum of all network algorithms (indegree, Katz status, pagerank, authority).

and dressing (0.680) and also in any form of erotic relation and life-partnership desire (0.801 to 0.565$)$. It is noticeable that this type does not include any dimension of mentality (e.g. desire for pleasant or personal discussion) or everyday sociability (companionship in or outside faculty). These dimensions appear to be insignificant. Such an (admittedly) important desire (namely erotic relation or life-partnership) seems to be strongly based on so superficial criteria, like physical appearance and dressing.

3) The "distant communicable"

Attractiveness for mailing per internet (0.438), sms (0.646) and phone calls (0.429) clearly demarcates a distinct type based on a slight intimacy. This type gains the intimacy feeling of the others enough to attract such a multiple communication but just this and no other kind of contact. It could be regarded as a type of safe and restricted contact.

4) The "fully narcissistically exploitable"

This type attracts both mild (0.534) and sharp (0.739) comments of improvement. Such a target appears to be a clear and attractive one for such exploitation without any further clear perspectives (e.g. life-partnership, pleasant discussion).

5) The "life-long exploitable"

This type is desired for short erotic relation (0.482) with the perspective of life-partnership without (0.446) or with (0.485) children. Of course, such a type is expected by his "admirers" (and possible future "life-partners") to fully respond to their criteria. They demand his conformation in a mild $(0.400,0.627)$ or sharp $(0.436)$ way.

\section{Discussion}

The gender appears to be relevant for intimacy. One feels generally stronger intimacy with male students for developing pleasant discussions. The tendency of preferring male students for developing pleasant discussions 
Table 8. Intimacy typology.

\begin{tabular}{|c|c|c|c|c|c|}
\hline & The "friend" & The "erotic" & $\begin{array}{l}\text { The "distant } \\
\text { communicable" }\end{array}$ & $\begin{array}{l}\text { The "fully } \\
\text { narcissistically } \\
\text { exploitable" }\end{array}$ & $\begin{array}{l}\text { The "life-long } \\
\text { exploitable" }\end{array}$ \\
\hline $\begin{array}{l}\text { Attractiveness for companionship } \\
\text { in the faculty (indegree) }\end{array}$ & 0.773 & -0.037 & 0.166 & -0.076 & -0.064 \\
\hline $\begin{array}{l}\text { Attractiveness for companionship } \\
\text { outside the faculty (indegree) }\end{array}$ & 0.803 & -0.263 & 0.158 & 0.082 & -0.099 \\
\hline $\begin{array}{l}\text { Attractiveness for mailing } \\
\text { per internet (indegree) }\end{array}$ & 0.763 & -0.150 & 0.438 & -0.023 & -0.090 \\
\hline Attractiveness for sms (indegree) & 0.557 & -0.139 & 0.646 & 0.024 & -0.253 \\
\hline Attractiveness for phone calls (indegeree) & 0.795 & -0.221 & 0.314 & 0.138 & -0.130 \\
\hline Attractiveness for phone calls (pagerank) & 0.628 & -0.198 & 0.429 & 0.068 & 0.014 \\
\hline Attractive physical appearance (indegree) & 0.636 & 0.435 & 0.115 & -0.470 & 0.109 \\
\hline Attractive dressing (indegree) & 0.711 & 0.289 & 0.006 & -0.455 & 0.215 \\
\hline Attractive dressing (pagerank) & 0.311 & 0.680 & 0.109 & -0.102 & -0.051 \\
\hline Attractive for pleasant discussion (indegree) & 0.872 & -0.139 & 0.143 & 0.012 & -0.071 \\
\hline Attractive for personal discussion (indegree) & 0.898 & -0.071 & 0.084 & 0.054 & -0.090 \\
\hline Attractive for durable erotic relation (indegree) & 0.205 & 0.801 & -0.088 & -0.037 & -0.226 \\
\hline Attractive for short erotic relation (indegree) & 0.329 & 0.818 & 0.046 & -0.017 & 0.131 \\
\hline Attractive for short erotic relation (authority) & 0.266 & 0.591 & 0.119 & -0.439 & 0.482 \\
\hline $\begin{array}{l}\text { Attractive for life-partnership } \\
\text { without children (indegree) }\end{array}$ & 0.345 & 0.788 & 0.028 & -0.060 & 0.076 \\
\hline $\begin{array}{l}\text { Attractive for life-partnership } \\
\text { without children (authority) }\end{array}$ & 0.247 & 0.566 & 0.173 & -0.448 & 0.446 \\
\hline $\begin{array}{l}\text { Attractive for life-partnership } \\
\text { with children (indegree) }\end{array}$ & 0.147 & 0.734 & -0.020 & 0.080 & 0.067 \\
\hline $\begin{array}{l}\text { Attractive for life-partnership with } \\
\text { children (authority) }\end{array}$ & 0.183 & 0.565 & 0.081 & -0.318 & 0.485 \\
\hline $\begin{array}{l}\text { Attractive for improving } \\
\text { comments in a mild way (indegree) }\end{array}$ & 0.492 & 0.189 & 0.051 & 0.534 & 0.400 \\
\hline $\begin{array}{l}\text { Attractive for improving } \\
\text { comments in a mild way (pagerank) }\end{array}$ & -0.018 & 0.276 & -0.031 & 0.184 & 0.627 \\
\hline $\begin{array}{l}\text { Attractive for improving } \\
\text { comments in a sharp way (indegree) }\end{array}$ & 0.173 & 0.173 & 0.333 & 0.739 & 0.436 \\
\hline
\end{tabular}

Extraction method: Principal component analysis. ${ }^{\mathrm{a}} 10$ components extracted.

can be attributed to the belief that relations with male students are characterized by less jealousness or competition. Thus, only the so-characterized as "depreciative" role remains available for the female students, meaning preferability for short erotic relations.

The more attractive physical appearance of the younger students is understandable as aging is affecting physical attractiveness and is often characterized by old-fashioned dressing which finds restricted acceptance.

The influence of the parents education level on the sociability and, thus, on the attractiveness for life partnership can be attributed to the social pedagogy exercised by the mother during childhood, which is decisive for the whole life of a person, while the high school grade appears to have an opposite effect, as it is regarded as an indicator of "hard work" and "no-relaxing".

The lack of physical attractiveness is expected to be outweighed by solutions connected with financial resources. This discloses a strategy of impressing and possibly satisfying narcissism, a deep need to feel attractive.

The short erotic relation is regarded as an indicator of depreciation, while durable erotic attractiveness is considered to be "sound" relation and a social or even existential justification. Thus, the ones who are preferred for 
durable erotic relation have the luxury to be independent of the thirds' appreciation and to ignore public opinion.

Contacting large companionship seems to produce a hope of finding out occasions for pleasant discussion or even for durable erotic relations. Either diagnosing socio-intellectual or emotional-sexual intensions and extensions of companionship, the quantity seems to become a means for fulfilling qualitative goals.

Multifarious dimensions of attractiveness (physical and non-physical ones) seem to be compatible with verbally-aggressive behaviors, as attractiveness generates both jealousness and familiarity. Attractive physical appearance as well as impressive dressing trigger competitiveness resulting to jealousness leading to verbal aggression. Simultaneously, persons attractive for pleasant or personal discussions normally disclose their personal weaknesses becoming thus an easy target for verbal aggressiveness.

Attractive students do not need to imagine desirable situations as they have them or they believe that they can have them. They find easy to develop cooperation or other kind of relation in reality. In general, the imagination seems to be a substitute for the lack of attractiveness.

There seems to be an extension of positive feeling from dressing to physical appearance or inversely. On the other hand, someone with unattractive physical appearance tends to be ineffective or even ridiculous, when dressed attractively. Thus, usually students with attractive physical appearance tend to be dressed attractively.

Normally, one tends to approach people with nice appearance or dressing in order to develop discussion. Thus, the visual impression appears to be a basic determinant for developing verbal communication. It would be reasonable to support that a discussion should as a rule be "personal" in order to be "pleasant" or it should be "pleasant" in order to be perceived as familiar and intimate enough and thereby as "personal".

The physical dimension appears to be stronger than mental parameters for maintaining a durable or short erotic relation. Hence, eroticism seems to be mostly based on the same physical parameters, independently of its long or short character. The simultaneity of attractiveness for short and durable erotic relation is a reasonable result as both cases tend to mostly depend on the same physical characteristics. Thus, the sustainability of erotic relation presents incidental character and unpredictability. On the other hand, the fact that the attractiveness for short erotic relation is correlated with durable one can also mean that the short one may function as a first stage (“testing”) for a durable one.

The afore-mentioned results are original but comparable and in general accordance with those of previous studies (Myers \& Huebner, 2011; Unal-Colak \& Kobak, 2011).

In general, a person attractive in a certain domain tends to be also attractive in other sectors. There is thus a tendency for extending initimacy.

Targeting for verbal aggressiveness tends to be extended simultaneously in various subjects and ways, supporting previous studies (Infante \& Wigley, 1986; Infante \& Rancer, 1996). These results are comparable with the results of Bekiari and Hasanagas (2015). Intimacy and verbal aggressiveness seem to function in similar extentionist pattern. The aggressors tend to generalize the impression of vulnerability on each individual target. For this reason, the targeting is extended and generalized on each person.

Finally, the proposed typology consist on quite original results. The only partial compatibility of all types of intimacy which justifies and sets the basis of constructing a typology implies that the dimensions of the idea called "intimacy" constitute really different properties in the social interaction. The type of "friend" attracts persons who are simultaneously fastidious toward him. The "erotic" patterns seem to be based on superficial criteria. The tendency to insist on "distant communication" can also be attributed to a certain intellectual-linguistic potential these persons possess. The "fully narcissistically exploitable" type is regarded as an idol rather than as a social entity who presents certain real "positive" features and are considered by their "admirers" to have capacity of further "improvement". These comments, thus, are mainly based on imaginary expectations and ideals not grounded on the reality. The "life-long exploitable" type is connected with strong demands for conformation, due to the expected long-term exploitation.

\section{Conclusions}

Attractiveness for pleasant discussions seems to be strongly gender-specific, as it is connected with male students, necessitating climate free of jealousness. Age-specific aesthetic racism also appears as younger students tend to be more attractive in physical appearance and dressing. Thereby, it could be argued that the young age and the attractive physical appearance tend to determine the dominant fashion too. The mother's pedagogic influence becomes evident through the effect of her education level on the attractiveness of someone for life- 
partnership to the extent that this depends on the sociability. The academic conformity (expressed by the high school grade) is not conducive to the development of pleasant discussions. Spending money for entertainment and impressing seems to be a practice against the impacts of not attractive physical appearance. Being aware of preference for durable erotic relation strengthens self-confidence in contrast to the preference for short erotic relation.

A companionship seems to be of socio-intellectual (developing discussion) or of emotional-sexual (erotic relation) nature. In general, attractiveness seems to lead to verbal aggression. Thus, attractiveness leads to targeting and vulnerability induced by the intimacy rather than to invulnerability due to expected admiration. However, attractiveness seems also to make life sense as it reduces the tendency to escape to imaginary sceneries.

Feelings of attractiveness and intimate relations such as pleasant discussion tend to be generalized rather than to analytical separated. Physical dimension appears to be stronger than mental parameters for maintaining a durable erotic relation, though mentality is often supposed to be as the cornerstone of a durable erotic relation.

The desire for life-partnership without children appears to be favored by mental elements such as the attractiveness for personal discussion. Verbal-aggressors search for targets without meticulously examining and pondering weaknesses and strengths on each person, tending to generalize the impression of vulnerability on each individual target.

Distinct types of attractiveness are also detected, corresponding to the following patterns: general sociability ("friend") which is also connected with mild (narcissistic) exploitation, erotic relation ("erotic") which is an autonomous value system based on superficial criteria related to appearance, focusing on communication ("distant communicable"), being an idol ("fully narcissistically exploitable") without any reality basis, and life-long occupation of a person ("life-long exploitable”).

\section{References}

Bekiari, A. (2012). Perceptions of Instructors’ Verbal Aggressiveness and Physical Education Students’ Affective Learning. Perceptual and Motor Skills, 115, 325-335. http://dx.doi.org/10.2466/06.11.16.PMS.115.4.325-335

Bekiari, A. (2014). Verbal Aggressiveness and Leadership Style of Sport Instructors and Their Relationship with Athletes' Intrinsic Motivation. Creative Education, 5, 114-121. http://dx.doi.org/10.4236/ce.2014.52018

Bekiari, A., \& Hasanagas, N. (2015). Verbal Aggressiveness Exploration through Complete Social Network Analysis: Using Physical Education Students' Class as an Illustration. International Journal of Social Science Studies, 3, 30-49. http://dx.doi.org/10.11114/ijsss.v3i3.729

Berscheid, E., \& Hatfield-Walster, E. (1969). Interpersonal Attraction. Menlo Park, CA: Addison-Wesley.

Bickson, D., \& Malkhi, D. (2008). A Unifying Framework of Rating Users and Data Items in Peer-to-Peer and Social Networks. Peer-to-Peer Networking and Applications, 1, 93-103. http://dx.doi.org/10.1007/s12083-008-0008-4

Cook, K. S., \& Emerson, R. M. (1978). Power, Equity and Commitment in Exchange Networks. American Sociological Review, 43, 721-739. http://dx.doi.org/10.2307/2094546

Edwards, A., \& Edwards, C. (2001). The Impact of Instructor Verbal and Nonverbal Immediacy on Student Perceptions of Attractiveness and Homophily. Journal of Excellence in College Teaching, 12, 5-17.

Evans, C. (2001). Nominal Rigidities and the Dynamic Effects of a Shock to Monetary Policy. NBER Working Paper 8403.

Foster, I., Kesselman, C., \& Tuecke, S. (2001). The Anatomy of the Grid: Enabling Scalable Virtual Organizations. International Journal of High Performance Computing Applications, 15, 200-222. http://dx.doi.org/10.1177/109434200101500302

Giddens, A. (1992). The Transformation of Intimacy: Sexuality. Love \& Eroticism in Modern Societies. Cambridge: Polity Press.

Hasanagas, N. D. (2009). Erotic Relation as Power Game: An Essay on Existential Imperialism. The Black Ribbon Campaign. http://nzmera.orconhosting.net.nz/powrgame.html

Infante, D. A., \& Rancer, A. S. (1996). Argumentativeness and Verbal Aggressiveness: A Review of Recent Theory and Research. Communication Yearbook, 19, 319-351.

Infante, D. A., \& Wigley, C. J. (1986). Verbal Aggressiveness: An Interpersonal Model and Measure. Communication Monographs, 53, 61-69. http://dx.doi.org/10.1080/03637758609376126

Infante, D. A., Myers, S. A., \& Buerkel, R. A. (1994). Argument and Verbal Aggression in Constructive and Destructive Family and Organizational Disagreements. Western Journal of Communication, 58, 73-84. http://dx.doi.org/10.1080/10570319409374488

Jordan, G., \& Schubert, K. (1992). A Preliminary Ordering of Policy Network Labels. European Journal of Political Research, 21, 7-27. http://dx.doi.org/10.1111/j.1475-6765.1992.tb00286.x 
Katz, L. (1953). A New Status Index Derived from Sociometric Analysis. Psychometrika, 18, 39-43. http://dx.doi.org/10.1007/BF02289026

Kelly, G. F. (1998). Sexuality Today: The Human Perspective. New York: McGraw-Hill.

Martin, M. M., \& Anderson, C. M. (1996). Argumentativeness and Verbal Aggressiveness. Journal of Social Behavior and Personality, 11, 547-554.

Martin, M. M., Weber, K., \& Burant, P. A. (1997). Students’ Perceptions of a Teacher's Use of Slang and Verbal Aggressiveness in a Lecture: An Experiment. Paper Presented at the Annual Meeting of the Eastern Communication Association, Baltimore.

McCroskey, J. C., \& McCain, T. A. (1974). The Measurement of Interpersonal Attraction. Speech Monographs, 41, $261-266$. http://dx.doi.org/10.1080/03637757409375845

McCroskey, J. C., Hamilton, P. R., \& Weiner, A. N. (1974). The Effect of Interaction Behavior on Source Credibility, Homophily, and Interpersonal Attraction. Human Communication Research, 1, 42-52. http://dx.doi.org/10.1111/j.1468-2958.1974.tb00252.x

McCroskey, L. L., McCroskey, J. C., \& Richmond, V. P. (2006). Analysis and Improvement of the Measurement of Interpersonal Attraction and Homophily. Communication Quarterly, 54, 1-31. http://dx.doi.org/10.1080/01463370500270322

Myers, S. A. (2001). Perceived Instructor Credibility and Verbal Aggressiveness in the College Classroom. Communication Research Reports, 18, 354-364. http://dx.doi.org/10.1080/08824090109384816

Myers, S. A. (2002). Perceived Aggressive Instructor Communication and Student State Motivation, Learning and Satisfaction. Communication Reports, 15, 113-121. http://dx.doi.org/10.1080/08934210209367758

Myers, S. A. (2003). Argumentativeness and Aggressiveness Research in Instructional Communication Contexts. Paper presented at the Annual Meeting of the Eastern Communication Association, Washington DC.

Myers, S. A., \& Huebner, A. D. (2011). The Relationship between students' Motives to Communicate with Their Instructors and Perceived Instructor Credibility, Attractiveness. and Homophily. College Student Journal, 45, 84-91.

Myers, S. A., \& Members of COM 200 Creighton University (2003). Perceived Instructor Affinity Seeking and Verbal Aggressiveness in the College Classroom. North Dakota Journal of Speech and Theatre, 16, 9-18.

Popitz, H. (1992). Phänomene der Macht. Tuebingen: J.C.B. Mohr.

Rocca, K. A., \& McCroskey, J. C. (1999). The Interrelationship of Student Ratings of Instructors’ Immediacy, Verbal Aggressiveness, Homophily, and Interpersonal Attraction. Communication Education, 48, 308-316. http://dx.doi.org/10.1080/03634529909379181

Skvoretz, J., \& Willer, D. (1993). Exclusion and Power: A Test of Four Theories of Power in Exchange Networks. American Sociological Review, 58, 801-818. http://dx.doi.org/10.2307/2095952

Unal-Colak, F., \& Kobak-Uzun, K. (2011). Determining Interpersonal Attraction in Educational Environment and the Relation with Motivation. International Journal on New Trends in Education and Their Implications, 2, 47-56.

Vogt, P. R. (1997). Hummock Fields in the Norway Basin and Eastern Iceland Plateau: Rayleigh-Taylor Instabilities? Geology, 25, 531-534. http://dx.doi.org/10.1130/0091-7613(1997)025<0531:HFITNB >2.3.CO;2

Weiss, S. D., \& Houser, M. L. (2007). Student Communication Motives and Interpersonal Attraction toward Instructor. Communication Research Reports, 24, 215-224. http://dx.doi.org/10.1080/08824090701439091 